\title{
Differentiation of mixtures of co-product blend with barley grain based on Fourier transform infrared attenuated total reflection molecular spectroscopy: Carbohydrate molecular spectral profiles and nutritive characteristics in dairy cattle
}

\author{
Xuewei Zhang ${ }^{1}$ and Peiqiang $\mathrm{Yu}^{2}$ \\ Department of Animal and Poultry Science, College of Agriculture and Bioresources, University of Saskatchewan, Saskatoon, \\ Saskatchewan, S7N 5A8, Canada
}

\begin{abstract}
The objectives of this study were to (1) differentiate mixtures of a co-product blend (70:30\% mixture of wheat:corn before bioethanol fermentation) from bioethanol processing with barley grain based on Fourier transform infrared attenuated total reflection molecular spectroscopy with cluster analysis, (2) elucidate the effects of the co-product blend on the molecular structure spectral profile and nutritive characteristics of the hullless barley carbohydrate (CHO) in dairy cattle, and (3) quantify the relationship between the $\mathrm{CHO}$ molecular structure spectral profiles and $\mathrm{CHO}$ nutritive characteristics of the mixtures in dairy cattle. The parameters assessed for $\mathrm{CHO}$ molecular structure spectral profiles included molecular spectral peak area and height intensities of lignin, structural CHO (STCHO), cellulosic compounds, and total CHO. The parameters assessed for $\mathrm{CHO}$ nutritive characteristics included the $\mathrm{CHO}$ nutrient profiles, $\mathrm{CHO}$ subfractions, energy values, and rumen-fermentable organic matter supply. Hull-less barley grains and the co-product blend were mixed according to the ratio of 100:0 (B100), 75:25, 50:50, 25:75, and 0:100 (BD100). The results showed that when the co-product blend was included at the different ratios, the predicted rumen-fermentable organic matter supply in the rumen was significantly decreased from 632 (B100) to $518 \mathrm{~g} / \mathrm{kg}$ of dry matter (DM; BD100). The effective degradable dry matter in the rumen and the effective degradable starch in the rumen were also significantly decreased from 672 and $482 \mathrm{~g} / \mathrm{kg}$ of DM (B100) to 475 and $43 \mathrm{~g} / \mathrm{kg}$ of DM (BD100), respectively. By using Fourier transform infrared attenuated total reflection spectroscopy, we identified were significant changes in the spectral profiles of the $\mathrm{CHO}$ molecular structure in
\end{abstract}

\footnotetext{
Received February 20, 2012.

Accepted July 2, 2012.

${ }^{1}$ Current address: Department of Animal Science, Tianjin Agricultural University, Tianjin, China 300384.

${ }^{2}$ Corresponding author: peiqiang.yu@usask.ca
}

terms of lignin, STCHO, cellulosic compounds, and total CHO spectral peak area and height and their ratios. Pearson analysis results suggested strong correlations between lignin peak area, cellulosic compound area, and total $\mathrm{CHO}$ peak area and $\mathrm{CHO}$ nutrient profiles except energy values (net energy for lactation at 3 times maintenance intake, net energy for maintenance, and net energy for gain). No correlation was observed between STCHO peak area and $\mathrm{CHO}$ nutrient profiles in the mixture samples.

Key words: carbohydrate molecular structure spectral profile, nutritive characteristic of carbohydrate, feed mixture

\section{INTRODUCTION}

Hull-less barley has been developed primarily for swine and poultry feeding (Bhatty, 1986, 1999). With alteration of the carbohydrate (CHO) molecular structure, such as the amylose-to-amylopectin ratio and $\beta$-glucan contents (Damiran and Yu, 2010, 2012), hull-less barley can be utilized more efficiently by dairy cattle. Hull-less barley is characterized by the spontaneous loss of hulls during harvest (Yang et al., 1997). It has greater concentrations of protein and starch but lower fiber concentration than hulled cultivars (Ramsey et al., 2001). Therefore, it has a very high degradation rate and extent, which may cause subacute rumen acidosis, laminitis, and bloats in the feedlot cattle (Zinn et al., 1996; Yang et al., 1997). However, with alterations of the CHO structure conformation, the nutrient availability of hull-less barley could be improved (Damiran and $\mathrm{Yu}, 2010,2012$ )

The co-products from bioethanol processing usually contain high RUP and low degradation rate (NuezOrtín and Yu, 2009, 2010a,b). It is expected that when the bioethanol co-products are added to hull-less barley, the rumen degradation and nutritive characteristics of both protein and $\mathrm{CHO}$ in hull-less barley will be more favorable to the dairy cow. The hourly effective N-to-energy ratio will be more synchronized in dairy 
cows and provide close to an optimal degradation ratio (25 to $32 \mathrm{~g}$ of $\mathrm{N} / \mathrm{kg}$ of CHO; Tamminga et al., 1994; Nuez-Ortín and Yu, 2010b). The favorable N-to-energy ratio will have the potential to decrease the incidence of rumen subacute acidosis in dairy cattle.

Recently studies showed that Fourier transform infrared attenuated total reflection (FT/IR-ATR) molecular spectroscopy is a powerful analytical tool to link feed chemistry information to molecular structure information and can be used to study feeds and nutrition on a molecular basis (Doiron et al., 2009; Yu, 2010; Yu et al., 2009, 2011; Jonker et al., 2012). Previous studies have shown correlations between the spectral profiles of feed molecular structure and their nutrient characteristics (Yu, 2012; Abeysekara et al., 2011). Zhang and $\mathrm{Yu}$ (2012) reported the spectral profile of the protein molecular structure in relation to protein availability in the co-product blend and barley. To date, no study has examined the effects of inclusion rate of the co-product blend on the spectral profiles of the $\mathrm{CHO}$ molecular structure in relation to $\mathrm{CHO}$ nutrient utilization of the hull-less barley in dairy cattle.

The hypothesis of this study was that by integrating hull-less barley grain with bioethanol co-products, the CHO utilization [in terms of fermentable OM (FOM) and energy supply in the rumen] of the barley could be improved. The N-to-energy synchronization ratio could be more optimal. The nutritive characteristics of $\mathrm{CHO}$ were associated with $\mathrm{CHO}$ molecular spectral profiles in the mixtures. The objectives of this study were to (1) elucidate the effects of inclusion rate of the co-product blend on the spectral profiles of the molecular structural and nutritive characteristics of the $\mathrm{CHO}$ in hull-less barley for dairy cattle; (2) differentiate mixtures of the co-product blend with barley grain based on FT/ITATR molecular spectroscopy with cluster analysis; and (3) quantify the relationship between spectral profiles of the $\mathrm{CHO}$ molecular structure and $\mathrm{CHO}$ nutritive characteristics of the mixtures in dairy cattle.

\section{MATERIALS AND METHODS}

\section{Hull-less Barley and Co-product Blend Mixtures}

In this study, CDC McGwire hull-less barley with normal starch traits (Damiran and Yu, 2010) and a coproduct blend from bioethanol processing (a blend of distillers dried grains with solubles: 70:30\% mixture of wheat:corn before bioethanol fermentation) were mixed at 5 different ratios: 100:0 (B100), 75:25 (B75BD25), 50:50 (B50BD50), 25:75 (B25BD75), and 0:100 (BD100), respectively. Before FT/IR-ATR spectral determination and chemical analysis, all samples were ground to pass through a 1-mm screen (Retsch ZM-
1; Brinkmann Instruments Ltd., Mississauga, ON, Canada).

\section{FT/IR-ATR Spectroscopic Investigations}

The FT/IR-ATR spectroscopic experiments were conducted at the University of Saskatchewan. The molecular spectral data were collected from the feed mixtures samples by using a Jasco FT/IR-ATR-4200 instrument (Jasco Corporation, Tokyo, Japan). Thirtytwo scans per sample were collected in the midinfrared range from 4,000 to $700 \mathrm{~cm}^{-1}$ in transmission mode at a spectral resolution of $4 \mathrm{~cm}^{-1}$. The collected spectra were corrected against air as the background (Jonker et al., 2012).

\section{Univariate CHO Molecular Spectral Analysis}

The software OMNIC 7.2 (Spectra Tech, Madison, WI) was used for spectral data analysis. The spectral parameters of the $\mathrm{CHO}$ molecular structure, including the lignin, structural CHO (STCHO), cellulosic compounds, and total $\mathrm{CHO}$ peak area and height, as well as their ratios, were studied (Figure 1). Chemical function groups were identified according to published reports (Himmelsbach et al., 1998; Wetzel et al., 1998; Wetzel, 2001; Marinkovic and Chance, 2006; Yu et al., 2011). The spectral region of analysis in this study was approximately 1,539 to $946 \mathrm{~cm}^{-1}$. The region and baseline of the lignin peak area and height were approximately 1,539 to $1,504 \mathrm{~cm}^{-1}$. For the STCHO, which is mainly associated with hemicellulosic and cellulosic compounds, the peak area and height region and baseline were approximately 1,485 to $1,186 \mathrm{~cm}^{-1}$, and 3 subpeaks were found in this region, whose heights were $1,415,1,370$, and $1,240 \mathrm{~cm}^{-1}$, respectively. The peak area region mainly associated with cellulosic compounds was at approximately 1,272 to $1,186 \mathrm{~cm}^{-1}$ (height centered at approximately $\left.1,240 \mathrm{~cm}^{-1}\right)$. The peaks area region mainly associated with $\mathrm{CHO}$ was at approximately 1,186 to $946 \mathrm{~cm}^{-1}$. Again, 3 subpeaks were found in this region, with peak area regions being approximately 1,186 to $1,132,1,132$ to 1,066 , and 1,066 to $946 \mathrm{~cm}^{-1}$ and the peak centers at 1,152,1,080, and $1,025 \mathrm{~cm}^{-1}$, respectively. Different ratios were calculated according to the respective absorbance intensity values.

\section{Multivariate CHO Molecular Spectral Analysis}

The FT/IR-ATR CHO fingerprint spectral data of hull-less barley and the co-product blend mixtures were analyzed by agglomerative hierarchical cluster analysis and principal components analysis using Statistica 8.0 software (StatSoft Inc., Tulsa, OK). These results were 


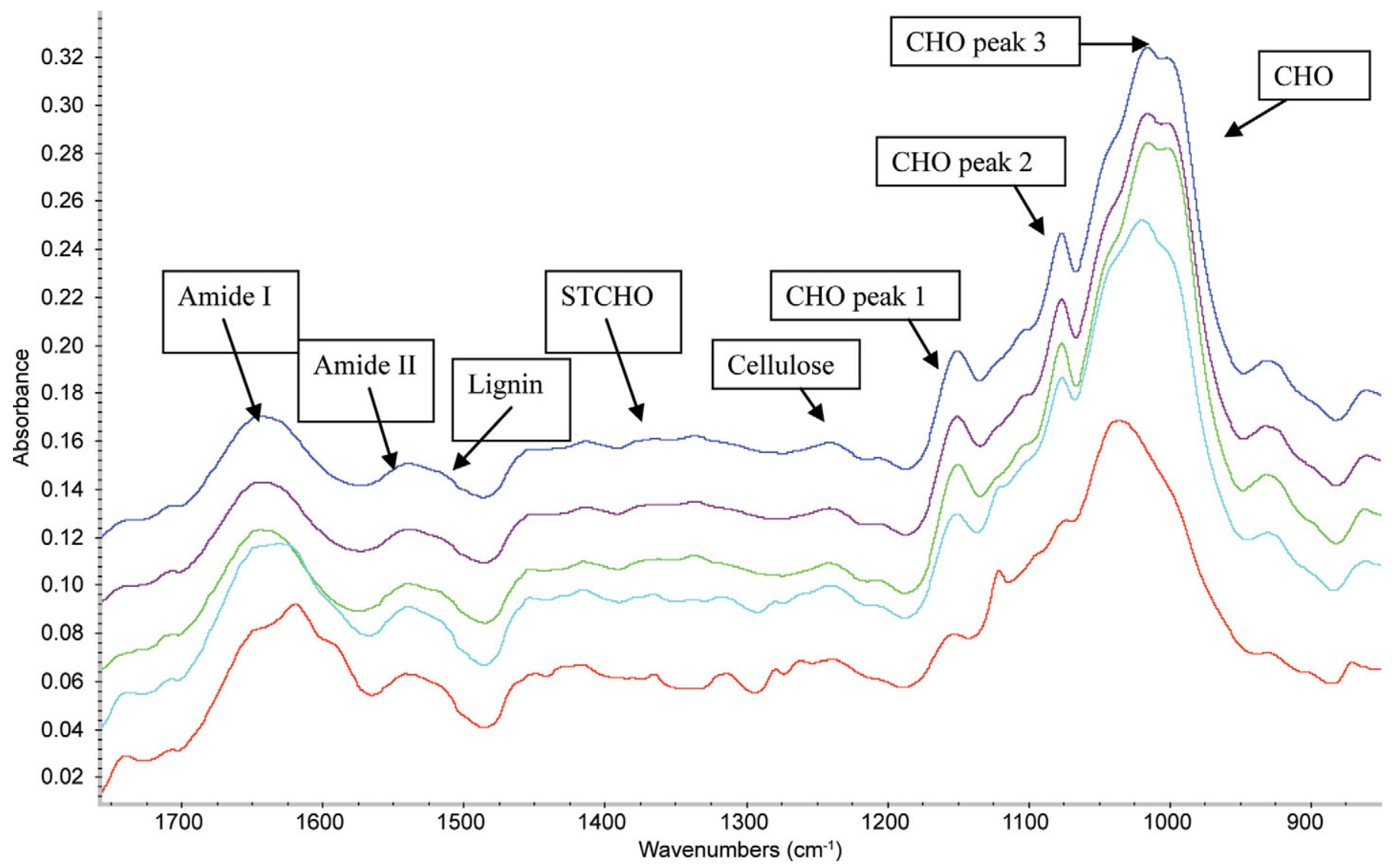

Figure 1. Fourier transform infrared attenuated total reflection molecular spectra of carbohydrate (CHO) molecular structures of the mixtures of a bioethanol processing co-product blend with barley grain, obtained using a Jasco FT/IR-ATR 4200 instrument (Jasco Corporation, Tokyo, Japan; spectral region: $\sim 1,539-946 \mathrm{~cm}^{-1}$ ). Mixtures: B100 $=100 \%$ barley; B75BD25 $=75 \%$ barley $+25 \%$ distillers dried grains with solubles (DDGS) blend; B50BD50 = 50\% barley $+50 \%$ DDGS blend; B25BD75 $=25 \%$ barley $+75 \%$ DDGS blend; BD100 $=100 \%$ DDGS blend. STCHO = structural CHO. Color version available in the online PDF.

able to classify and distinguish inherent $\mathrm{CHO}$ structural differences among the different mixtures, and then identify the main sources of variation within the lignin, STCHO, and CHO fingerprint spectra $(\sim 1,539$ to 946 $\mathrm{cm}^{-1}$; Yu, 2005).

\section{Animals and Diets}

The experiment protocol was reviewed and approved by the Animal Care Committee of Saskatchewan and was conducted in accordance with the guidelines of the Canadian Council on Animal Care (CCAC, 1993). Three nonlactating Holstein cows with flexible rumen cannulas (10 cm i.d., Bar Diamond Inc., Parma, ID) were used in this study to determine the in situ degradation kinetics of the mixtures of hull-less barley and co-product blend. The cows were fed $20.5 \mathrm{~kg} / \mathrm{d}$ of a TMR (barley silage:standard dairy concentrate was 78:22\%) according to NRC (2001) recommendations. The concentrate consisted of $63.9 \%$ rolled barley,
$35.0 \%$ standard dairy supplement (containing barley, wheat, oats, dairy supplement pellets, and molasses), $1.0 \%$ fresh dairy cow supplement [containing barley, oats, canola meal, soybean meal, wheat distillers dried grains with solubles, corn gluten meal, molasses, dried fat supplement (golden flakes), canola oil, minerals, and vitamins], and $0.1 \%$ mold control. The cows were housed in the animal nutritive experimental station, University of Saskatchewan, and fed half of the ration twice daily at 0800 and 1600 h. Fresh, clean water was supplied ad libitum.

\section{Rumen In Situ Incubation}

According to the in situ method (Yu et al., 2003), approximately $7 \mathrm{~g}$ of each mixture sample (ground to pass through a $0.5-\mathrm{mm}$ screen) was placed into each numbered nylon bag (Nitex 03-41/31 monofilament open mesh fabric; Screentec Crop., Mississauga, ON, Canada) measuring $10 \times 20 \mathrm{~cm}$ with a pore size of 
approximately $40 \mu \mathrm{m}$. The bags were added according to the gradual addition-all out schedule. The multiple bags for each treatment at each incubation time in each experimental run were $2,2,2,3,3$, and 4 bags for incubation times $0,4,8,12,24$, and $48 \mathrm{~h}$, respectively. Treatments were randomly assigned to 3 nonlactating cows in 2 experimental runs. After incubation, the bags were taken out of the rumen and, including those samples for $0 \mathrm{~h}$, washed with cold water several times, and then dried at $55^{\circ} \mathrm{C}$ for $48 \mathrm{~h}$. The dried samples were stored in a refrigerated room $\left(4^{\circ} \mathrm{C}\right)$ until chemical analysis.

Rumen degradation characteristics of starch were determined using the NLIN procedure of SAS v9.2 (SAS Institute, 2005) based on the first-order kinetics equations (Ørskov and McDonald, 1979; Tamminga et al., 1994):

$$
\mathrm{R}(\mathrm{t})=\mathrm{D} \times \exp ^{\left(-\mathrm{K}_{\mathrm{d}} \times \mathrm{t}\right)}
$$

where $\mathrm{R}(\mathrm{t})$ is the residue of the incubated material after $\mathrm{t} \mathrm{h}$ of rumen incubation (\%); D (in \%) is the undegradable and potentially degradable fractions, respectively; and degradation rate $\left(\mathrm{K}_{\mathrm{d}}\right)$ is the percentage rate per hour.

\section{Chemical Analysis}

Dry matter, ash, ether extract (EE), and CP were measured according to the method of the Association of Official Analytical Chemists (AOAC, 1990). For starch determination, samples were ground to pass through a $0.5-\mathrm{mm}$ screen and analyzed using the method of the Megazyme Total Starch Assay Kit (Megazyme International, Bray, Co. Wicklow, Ireland) and by the $\alpha$-amylase/amyloglucosidase method (McCleary et al. 1997). Neutral detergent fiber, ADF, and ADL were analyzed according to the filtration method (Van Soest et al., 1991). Total $\mathrm{CHO}$ were calculated as $\mathrm{CHO}=$ 100 - EE - CP - ash. Similarly, other CHO were calculated as NFC $=100-(\mathrm{NDF}-\mathrm{NDICP})-\mathrm{EE}-$ $\mathrm{CP}$ - ash (where NDICP is neutral detergent-insoluble $\mathrm{CP})$, hemicellulose $=\mathrm{NDF}-\mathrm{ADF}$, and cellulose $=$ ADF - ADL (NRC, 2001).

\section{CHO Subfraction Partitioning}

Carbohydrate fractions of the mixtures were partitioned into $\mathrm{CA}, \mathrm{CB}_{1}, \mathrm{CB}_{2}$, and $\mathrm{CC}$ (Sniffen et al., 1992; Fox et al., 2007). Fraction CA was composed of sugars and organic acids, which had a rapid degradation rate of $300 \% / \mathrm{h}$, and was calculated as NFC minus $\mathrm{CB}_{1}(\mathrm{CA}$ $\left.=\mathrm{NFC}-\mathrm{CB}_{1}\right) ; \mathrm{CB}_{1}$ included starch and pectin, which had an intermediate degradation rate of 20 to $50 \% / \mathrm{h}$ $\left(\mathrm{CB}_{1}=\right.$ starch + pectin $) ; \mathrm{CB}_{2}$ was digestible cell walls, which had a slow degradation rate of 2 to $10 \% / \mathrm{h}$ and equaled $\mathrm{NDF}_{\mathrm{n} \text {-free }}$ minus $\mathrm{CC}\left[\mathrm{CB}_{2}=(\mathrm{NDF}-\mathrm{NDICP})\right.$ - $\mathrm{CC}]$; $\mathrm{CC}$ was unavailable cell walls, which were unavailable $\mathrm{CHO}$ in the rumen and were calculated by lignin $[\mathrm{CC}=(\operatorname{lignin} \times 2.4) / 100]$.

\section{Estimation of Truly Digestible Nutrients and Energy Values}

Truly digestible NDF (tdNDF), truly digestible NFC $(\mathbf{t d N F C})$, and TDN at $1 \times$ maintenance $\left(\mathbf{T D N} \mathbf{N}_{\mathbf{1 \times}}\right)$ as well as energy values (digestible energy, ME, net energy) were determined using the NRC summary approach (NRC, 1996, 2001).

\section{Statistical Analysis}

CHO Molecular Structure Spectral Profiles of FT/IR-ATR, Rumen Degradation Kinetics, and Predicted Nutrient Supply. Statistical analysis was performed using the MIXED procedure of SAS 9.2 (SAS Institute, 2005) using a complete randomized design. The model used for analysis was $Y_{i j}=\mu+a_{i}+\varepsilon_{i j}$, where $Y_{i j}$ is an observation of the dependent variable $\mathrm{ij} ; \mu$ is the population mean for the variable; $\mathrm{a}_{\mathrm{i}}$ is the effect of the treatments ( 5 mixtures) as a fixed effect; and $\varepsilon_{\mathrm{ij}}$ is the random error associated with observation ij. The polynomial contrasts of linear, quadratic, and cubic effects were carried out using the mixed-methods procedure (PROC MIXED) with the contrast statement in SAS.

Correlation Analysis. The relationship between changes in the $\mathrm{CHO}$ molecular structure spectral profile and their ratios and $\mathrm{CHO}$ chemical and nutrient profiles, Cornell Net Carbohydrate and Protein System CHO fractions (Sniffen et al., 1992), in situ degradation kinetics, and predicted FOM supply to dairy cattle among the 5 mixtures were analyzed using PROC CORR of SAS v9.2 (Liu and Yu, 2010).

For all statistical analyses, significance was declared at $P<0.05$ and trends at $P \leq 0.10$. Treatment means were compared using Tukey's test.

\section{RESULTS AND DISCUSSION}

\section{Differences in CHO Molecular Spectral Profiles Among the Mixtures}

Univariate CHO Molecular Spectral Analysis. The differences in $\mathrm{CHO}$ spectral makeup among the hull-less barley and co-product blend mixtures were revealed by Jasco FT/IR-ATR spectroscopy and OM- 
NIC 7.2 software (Table 1). The results showed that the lignin peak centered at approximately $1,510 \mathrm{~cm}^{-1}$ and the peak area and height intensities of lignin were increased significantly $(P<0.01)$ from $0.057,0.003$ (B100) to 0.141, and 0.006 infrared absorbance units (BD100), respectively (Table 1 ). The lignin peak at approximately $1,510 \mathrm{~cm}^{-1}$ is mainly due to aromatic ring stretching in the lignin biopolymer (Himmelsbach et al., 1998). The peak area intensity of STCHO was decreased significantly in a quadratic fashion $(P<0.05)$, from 5.185 to 4.524 infrared absorbance units (Table 1 ). Normally, 3 relatively unique subpeaks were located in the STCHO region, with the peak I, II, and III centers at approximately $1,415,1,370$, and $1,240 \mathrm{~cm}^{-1}$, respectively (Wetzel et al., 1998). The intensities of STCHO peaks I and III were relatively increased in a linear or quadratic way, whereas the intensity of STCHO peak II was relatively decreased in a linear way $(P<0.01)$ with an increasing level of co-product blend. The peak area and height intensities of cellulosic compounds were linearly increased $(P<0.01)$, whereas all the subpeak area and height intensities in the total $\mathrm{CHO}$ region were linearly decreased $(P<0.01)$. In addition, the ratios of functional groups were linearly changed $(P<0.01)$ among the mixtures (Table 1$)$. In the literature, reports are limited on the $\mathrm{CHO}$ molecular spectral features in feed mixtures $(\mathrm{Yu}, 2012)$, so no comparison could be made. The results from this study indicated that molecular spectroscopy is sensitive to picking up the CHO molecular structural changes in the feed mixtures. Whether these $\mathrm{CHO}$ molecular structural changes were associated with nutritive characteristics of $\mathrm{CHO}$ in dairy cattle needs to be investigated in a future study.

Multivariate CHO Molecular Spectral Analysis. Figures 2 and 3 showed results of the cluster analysis and the PCA (Yu, 2005) of CHO molecular spectra in the broadband fingerprint region of approximately 1,539 to $946 \mathrm{~cm}^{-1}$ that was obtained from the feed mixtures. Results indicated that with the proportion of coproduct blend increasing in barley, the $\mathrm{CHO}$ structural makeup could gradually be distinguished and grouped into a separate ellipse. The first and second principal components explained 71.11 and $26.49 \%$ of the total variance, respectively. These results indicate that the treatments were related each other, although the structures of some of the treatments were different.

\section{Differences in CHO Chemical Profiles, $\mathrm{CHO}$ Fractionations, Truly Digestible Nutrients, and Energy Values Among the Mixtures}

Results of chemical analysis of the 5 mixtures of coproduct blends with barley grain are presented in Table 2 . The results showed that distinctive changes occurred in chemical compositions among the mixtures. With an increasing inclusion of co-product blend in the hull-less barley, DM content showed a linear decrease, with a mean of $930 \mathrm{~g} / \mathrm{kg}$ and a range of $14 \mathrm{~g} / \mathrm{kg}$. Ash and EE were increased by about 3 times, from 17 and $20 \mathrm{~g} /$ $\mathrm{kg}$ of DM (B100) to 42 and $61 \mathrm{~g} / \mathrm{kg}$ of DM (BD100). The concentrations of $\mathrm{CHO}$, starch, and NFC were decreased linearly from 816 to $524 \mathrm{~g} / \mathrm{kg}, 613$ to $58 \mathrm{~g} /$ $\mathrm{kg}$, and 730 to $233 \mathrm{~g} / \mathrm{kg}$ of DM (from B100 to BD100), respectively. However, the contents of NDF, ADF, and ADL were increased linearly from 100, 14, and 3 (B100) to 454,93 , and $20 \mathrm{~g} / \mathrm{kg}$ of DM (BD100). Similarly, the contents of hemicellulose and cellulose were increased linearly by about 4 and 7 times. These results are in agreement with a previous study on the predicted nutrient supply of corn with wheat distillers dried grains with solubles (Damiran et al., 2012)

The results (Table 2) indicated that $\mathrm{CA}$ and $\mathrm{CB}_{2}$ were increased linearly and $\mathrm{CC}$ was increased quadratically, whereas $\mathrm{CB}_{1}$ was decreased linearly from B100 to BD100. The results implied that the co-product blend added extra soluble sugars and available fiber and lignin but that it reduced the starch content in the mixtures to a great degree. The CHO fractions for the co-product blend and hull-less barley were similar to those reported by Nuez-Ortín and Yu (2009) and Damiran and $\mathrm{Yu}$ (2010). This result indicates that through different types of feed mixtures, the $\mathrm{CHO}$ subfraction profiles could be formulated to an optimal level, which would affect the degradation behaviors (Sniffen et al., 1992), available rumen-undegradable CHO (Cornell Net Carbohydrate and Protein System, v6.1), and hourly effective N-to-energy synchronization ratio (Tamminga et al., 1994; Nuez-Ortín and Yu, 2010b).

Truly digestible nutrients reflect the energy value of feedstuffs (NRC, 2001). With an increasing co-product blend inclusion rate in the mixtures with the hull-less barley, truly digestible $\mathrm{NFC}$ and $\mathrm{TDN}_{1 \times}$ were linearly decreased, whereas tdNDF was linearly increased. The values of $\mathrm{ME}_{\mathrm{p} 3 \times}(\mathrm{ME}$ at production level at 3 times maintenance intake) and $\mathrm{NE}_{\mathrm{L} 3 \times}\left(\mathrm{NE}_{\mathrm{L}}\right.$ at 3 times maintenance intake) for dairy cows showed a linear increase. However, no difference was observed in the values of $\mathrm{DE}_{1 \times}$, (digestible energy at maintenance level) $\mathrm{NE}_{\mathrm{M}}$, and $\mathrm{NE}_{\mathrm{G}}$ among the mixtures.

\section{Differences In Situ Rumen Degradation Kinetics Among the Mixtures}

The results of in situ rumen degradation analysis from the 5 co-product blend mixtures with hull-less barley are presented in Table 3 . In the characteristics of in situ starch rumen degradability, BST and effectively degradable starch in the rumen (EDST) were decreased 
Table 1. Molecular structure spectral characteristics (in terms of peak area and height intensity) of structural and nonstructural carbohydrates (CHO) in mixtures ${ }^{1}$ of a co-product blend with barley

\begin{tabular}{|c|c|c|c|c|c|c|c|c|c|c|}
\hline \multirow{2}{*}{$\begin{array}{l}\text { CHO molecular structure profiles }{ }^{2} \\
\text { (infrared absorbance intensity) }\end{array}$} & \multirow{2}{*}{$\begin{array}{l}\text { Region, baseline } \\
\text { or peak center } \\
\left(\mathrm{cm}^{-1}\right)\end{array}$} & \multirow[b]{2}{*}{$\mathrm{B} 100$} & \multirow[b]{2}{*}{ B75BD25 } & \multirow[b]{2}{*}{ B50BD50 } & \multirow[b]{2}{*}{ B25BD75 } & \multirow[b]{2}{*}{ BD100 } & \multirow[b]{2}{*}{ SEM } & \multicolumn{3}{|c|}{$P$-value } \\
\hline & & & & & & & & Linear & Quadratic & Cubic \\
\hline Lignin peak area & $\sim 1,539-1,504$ & $0.057^{\mathrm{d}}$ & $0.067^{\mathrm{d}}$ & $0.094^{c}$ & $0.110^{\mathrm{b}}$ & $0.141^{\mathrm{a}}$ & 0.0031 & $<0.001$ & 0.460 & 0.221 \\
\hline Lignin peak height & $\sim 1,510$ & $0.003^{\mathrm{c}}$ & $0.003^{\mathrm{c}}$ & $0.004^{\mathrm{b}}$ & $0.005^{\mathrm{b}}$ & $0.006^{\mathrm{a}}$ & 0.0002 & 0.211 & 0.378 & 0.257 \\
\hline Structural $\mathrm{CHO}$ area (STCHO) & $\sim 1,485-1,186$ & $5.185^{\mathrm{a}}$ & $4.595^{\mathrm{ab}}$ & $4.805^{\mathrm{ab}}$ & $4.543^{\mathrm{b}}$ & $4.524^{\mathrm{b}}$ & 0.1510 & 0.014 & 0.033 & 0.064 \\
\hline STCHO peak I height & $\sim 1,415$ & $0.026^{\mathrm{ab}}$ & $0.023^{\mathrm{b}}$ & $0.025^{\mathrm{b}}$ & $0.025^{\mathrm{b}}$ & $0.028^{\mathrm{a}}$ & 0.0008 & 0.009 & 0.323 & 0.209 \\
\hline STCHO peak II height & $\sim 1,370$ & $0.026^{\mathrm{a}}$ & $0.022^{\mathrm{b}}$ & $0.022^{\mathrm{b}}$ & $0.020^{\mathrm{b}}$ & $0.019^{\mathrm{b}}$ & 0.0008 & 0.005 & 0.137 & 0.145 \\
\hline STCHO peak III height & $\sim 1,240$ & $0.016^{\mathrm{b}}$ & $0.015^{\mathrm{b}}$ & $0.016^{\text {ab }}$ & $0.016^{\mathrm{ab}}$ & $0.018^{\mathrm{a}}$ & 0.0005 & $<0.001$ & 0.002 & 0.158 \\
\hline Cellulosic peak area & $\sim 1,272-1,213$ & $0.187^{\mathrm{cd}}$ & $0.183^{\mathrm{d}}$ & $0.216^{\mathrm{bc}}$ & $0.234^{\mathrm{b}}$ & $0.323^{\mathrm{a}}$ & 0.0074 & $<0.001$ & 0.774 & 0.264 \\
\hline Cellulosic peak height & $\sim 1,240$ & $0.007^{\mathrm{b}}$ & $0.006^{\mathrm{b}}$ & $0.007^{\mathrm{ab}}$ & $0.007^{\mathrm{ab}}$ & $0.008^{\mathrm{a}}$ & 0.0002 & $<0.001$ & 0.259 & 0.220 \\
\hline $\mathrm{CHO}$ area & $\sim 1,186-946$ & $20.436^{\mathrm{a}}$ & $16.840^{\mathrm{b}}$ & $16.790^{\mathrm{b}}$ & $14.741^{\mathrm{bc}}$ & $14.069^{\mathrm{c}}$ & 0.5983 & $<0.0001$ & 0.977 & 0.429 \\
\hline CHO peak I area & $\sim 1,186-1,132$ & $1.723^{\mathrm{a}}$ & $1.377^{\mathrm{b}}$ & $1.324^{\mathrm{b}}$ & $1.007^{\mathrm{c}}$ & $0.665^{\mathrm{d}}$ & 0.0511 & 0.509 & 0.032 & 0.063 \\
\hline $\mathrm{CHO}$ peak II area & $\sim 1,132-1,066$ & $4.279^{\mathrm{a}}$ & $3.587^{\mathrm{b}}$ & $3.696^{\mathrm{b}}$ & $3.631^{\mathrm{b}}$ & $3.929^{\mathrm{ab}}$ & 0.1297 & $<0.001$ & 0.307 & 0.257 \\
\hline CHO peak III area & $\sim 1.066-946$ & $14.440^{\mathrm{a}}$ & $11.872^{\mathrm{b}}$ & $11.770^{\mathrm{bc}}$ & $10.104^{\mathrm{cd}}$ & $9.477^{\mathrm{d}}$ & 0.4211 & $<0.0001$ & 0.776 & 0.425 \\
\hline CHO peak I height & $\sim 1,152$ & $0.060^{\mathrm{a}}$ & $0.048^{\mathrm{b}}$ & $0.045^{\mathrm{b}}$ & $0.035^{\mathrm{c}}$ & $0.025^{\mathrm{d}}$ & 0.0018 & 0.004 & 0.214 & 0.208 \\
\hline CHO peak II height & $\sim 1,080$ & $0.104^{\mathrm{a}}$ & $0.087^{\mathrm{b}}$ & $0.087^{\mathrm{b}}$ & $0.079^{\mathrm{b}}$ & $0.078^{\mathrm{b}}$ & 0.0030 & $<0.001$ & 0.232 & 0.326 \\
\hline CHO peak III height & $\sim 1,025$ & $0.197^{\mathrm{a}}$ & $0.161^{\mathrm{b}}$ & $0.157^{\mathrm{b}}$ & $0.131^{\mathrm{c}}$ & $0.126^{\mathrm{c}}$ & 0.0058 & $<0.001$ & 0.060 & 0.337 \\
\hline Area ratio of CHO peak I:II & & $0.402^{\mathrm{a}}$ & $0.384^{\mathrm{b}}$ & $0.358^{\mathrm{c}}$ & $0.276^{\mathrm{d}}$ & $0.169^{\mathrm{e}}$ & 0.0033 & $<0.001$ & 0.023 & 0.602 \\
\hline Area ratio of CHO peak I:III & & $0.119^{\mathrm{a}}$ & $0.116^{\mathrm{a}}$ & $0.112^{\mathrm{b}}$ & $0.099^{\mathrm{c}}$ & $0.070^{\mathrm{d}}$ & 0.0009 & $<0.001$ & 0.026 & 0.261 \\
\hline Area ratio of CHO peak II:III & & $0.296^{\mathrm{d}}$ & $0.302^{\mathrm{d}}$ & $0.314^{\mathrm{c}}$ & $0.360^{\mathrm{b}}$ & $0.415^{\mathrm{a}}$ & 0.0016 & $<0.001$ & 0.087 & 0.510 \\
\hline Height ratio of CHO peak I:II & & $0.572^{\mathrm{a}}$ & $0.552^{\mathrm{b}}$ & $0.521^{\mathrm{c}}$ & $0.443^{\mathrm{d}}$ & $0.323^{\mathrm{e}}$ & 0.0048 & $<0.001$ & 0.016 & 0.691 \\
\hline Height ratio of CHO peak I:III & & $0.302^{\mathrm{a}}$ & $0.298^{\mathrm{a}}$ & $0.289^{\mathrm{b}}$ & $0.267^{\mathrm{c}}$ & $0.199^{\mathrm{d}}$ & 0.0019 & $<0.001$ & 0.945 & 0.276 \\
\hline Height ratio of CHO peak II:III & & $0.528^{\mathrm{e}}$ & $0.539^{\mathrm{d}}$ & $0.556^{\mathrm{c}}$ & $0.602^{\mathrm{b}}$ & $0.616^{\mathrm{a}}$ & 0.0025 & $<0.001$ & 0.689 & 0.933 \\
\hline Area ratio of lignin:STCHO & & $0.003^{\mathrm{e}}$ & $0.004^{\mathrm{d}}$ & $0.006^{\mathrm{c}}$ & $0.007^{\mathrm{b}}$ & $0.010^{\mathrm{a}}$ & 0.0002 & $<0.001$ & $<0.001$ & 0.006 \\
\hline Area ratio of lignin: $\mathrm{CHO}$ & & $0.254^{\mathrm{e}}$ & $0.273^{\mathrm{d}}$ & $0.286^{\mathrm{c}}$ & $0.308^{\mathrm{b}}$ & $0.322^{\mathrm{a}}$ & 0.0017 & $<0.001$ & 0.511 & 0.684 \\
\hline Area ratio of STCHO:CHO & & $0.011^{\mathrm{e}}$ & $0.015^{\mathrm{d}}$ & $0.020^{\mathrm{c}}$ & $0.024^{\mathrm{b}}$ & $0.031^{\mathrm{a}}$ & 0.0005 & $<0.001$ & 0.549 & 0.786 \\
\hline Protein amide I peak area & $\sim 1,721-1,580$ & $6.916^{\mathrm{e}}$ & $56.916^{\mathrm{d}}$ & $66.916^{\mathrm{c}}$ & $76.916^{\mathrm{b}}$ & $86.916^{\mathrm{a}}$ & 0.9574 & $<0.001$ & 0.039 & 0.149 \\
\hline Area ratio of amide $\mathrm{I}: \mathrm{CHO}$ & & $0.352^{\mathrm{d}}$ & $3.390^{\mathrm{c}}$ & $4.012^{\mathrm{c}}$ & $5.323^{\mathrm{b}}$ & $6.211^{\mathrm{a}}$ & 0.1645 & $<0.001$ & 0.062 & 0.186 \\
\hline
\end{tabular}

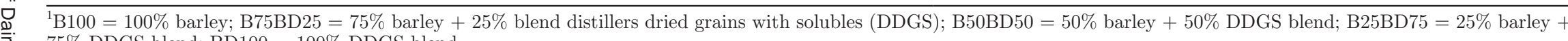
. $75 \%$ DDGS blend; BD100 = 100\% DDGS blend

ก) ${ }^{2}$ Analyses were conducted using a Jasco Fourier transform infrared attenuated total reflection molecular spectroscope (Jasco Corporation, Tokyo, Japan). 


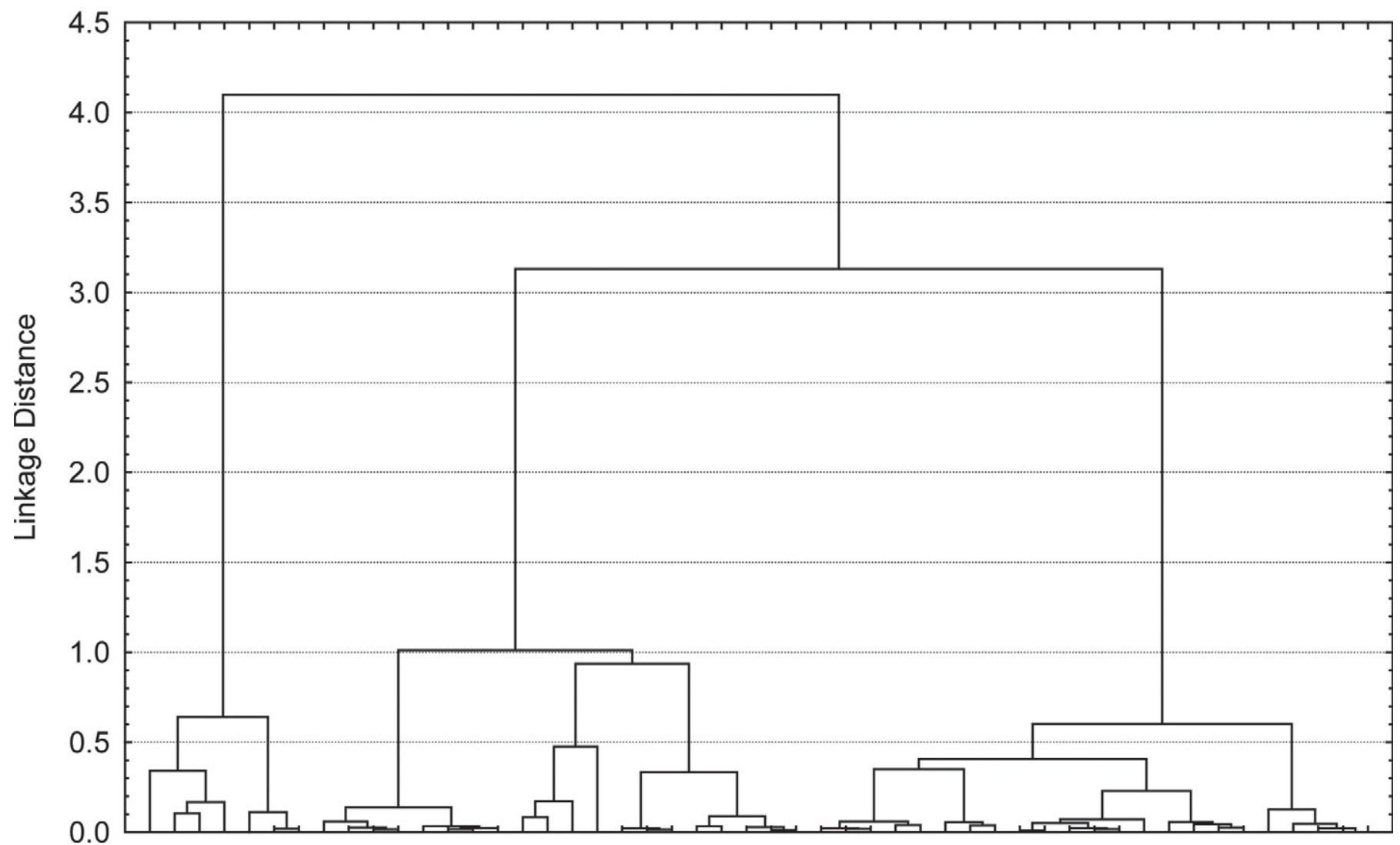

11111115555555555444444444433333333222321222132221

Figure 2. Agglomerative hierarchical cluster of Fourier transform infrared attenuated total reflection carbohydrate (CHO) spectra obtained from 5 mixtures of a bioethanol processing co-product blend with barley grain. Agglomerative hierarchical cluster analysis: (1) spectral region: $\sim 1,539-946 \mathrm{~cm}^{-1}$; (2) distant method: Euclidean; (3) cluster method: Ward's algorithm (Yu, 2005). $1=$ B100 = 100\% barley; $2=$ B75BD25 = $75 \%$ barley $+25 \%$ distillers dried grains with solubles (DDGS) blend; $3=$ B50BD50 $=50 \%$ barley $+50 \%$ DDGS blend; $4=$ B25BD75 $=25 \%$ barley $+75 \%$ DDGS blend; $5=$ BD100 $=100 \%$ DDGS blend. Color version available in the online PDF.

significantly from 130 and 482 (B100) to 15 and $43 \mathrm{~g} /$ $\mathrm{kg}$ of DM (BD100; $P<0.01)$. The results showed that the hull-less barley had a significantly greater EDST content $[482 \mathrm{~g} / \mathrm{kg}$ of FOM was decreased significantly from B100 $(632 \mathrm{~g} / \mathrm{kg}$ of DM) to BD100 $(518 \mathrm{~g} / \mathrm{kg}$ of $\mathrm{DM})$ ] and may explain why the $\mathrm{CHO}$ fractions $\mathrm{CA}$, $\mathrm{CB}_{2}$, and $\mathrm{CC}$ were increased but $\mathrm{CB}_{1}$ decreased linearly. The in situ results from the co-product blend and hull-less barley were similar to those previously reported by Nuez-Ortín and Yu (2009, 2010a,b) and Damiran and $\mathrm{Yu}$ (2012). The implication from these in situ results is that the rumen N-to-energy ratio could be manipulated through the feed mixtures of hull-less barley (greater energy and a greater degradation rate and extent) with the co-product blend (greater truly absorbable protein; lower degradation rate and extent) to an optimal degradation ratio of 25 to $32 \mathrm{~g}$ of $\mathrm{N} / \mathrm{kg}$ of CHO (Tamminga et al., 1994; Nuez-Ortín and Yu, 2010a,b).

\section{Relationship Between Spectral Characteristics of the $\mathrm{CHO}$ Molecular Structure and $\mathrm{CHO}$ Nutrient Profiles}

Pearson correlations of the $\mathrm{CHO}$ molecular structural characteristics determined by using FT/IR-ATR spectroscopy to determine $\mathrm{CHO}$ chemical composition, $\mathrm{CHO}$ fractionations, truly digestible nutrients, in situ degradation kinetics, and predicted FOM supply in the mixtures are presented in Table 4 . The results showed that the spectra of functional groups of lignin, cellulosic compounds, and total $\mathrm{CHO}$ were very sensitive to the feed mixtures.

First, the spectral infrared absorbance intensity of lignin and cellulosic compounds had a strongly negative correlation $(P<0.01)$ with $\mathrm{CHO}$, starch, NFC, $\mathrm{CB}_{1}$, tdNFC, $\mathrm{TDN}_{1 \times}$, and FOM but had a strongly positive correlation $(P<0.01)$ with NDF, ADF, ADL, hemicellulose, cellulose, tdNDF, $\mathrm{CB}_{2}$, and CC. A significant 


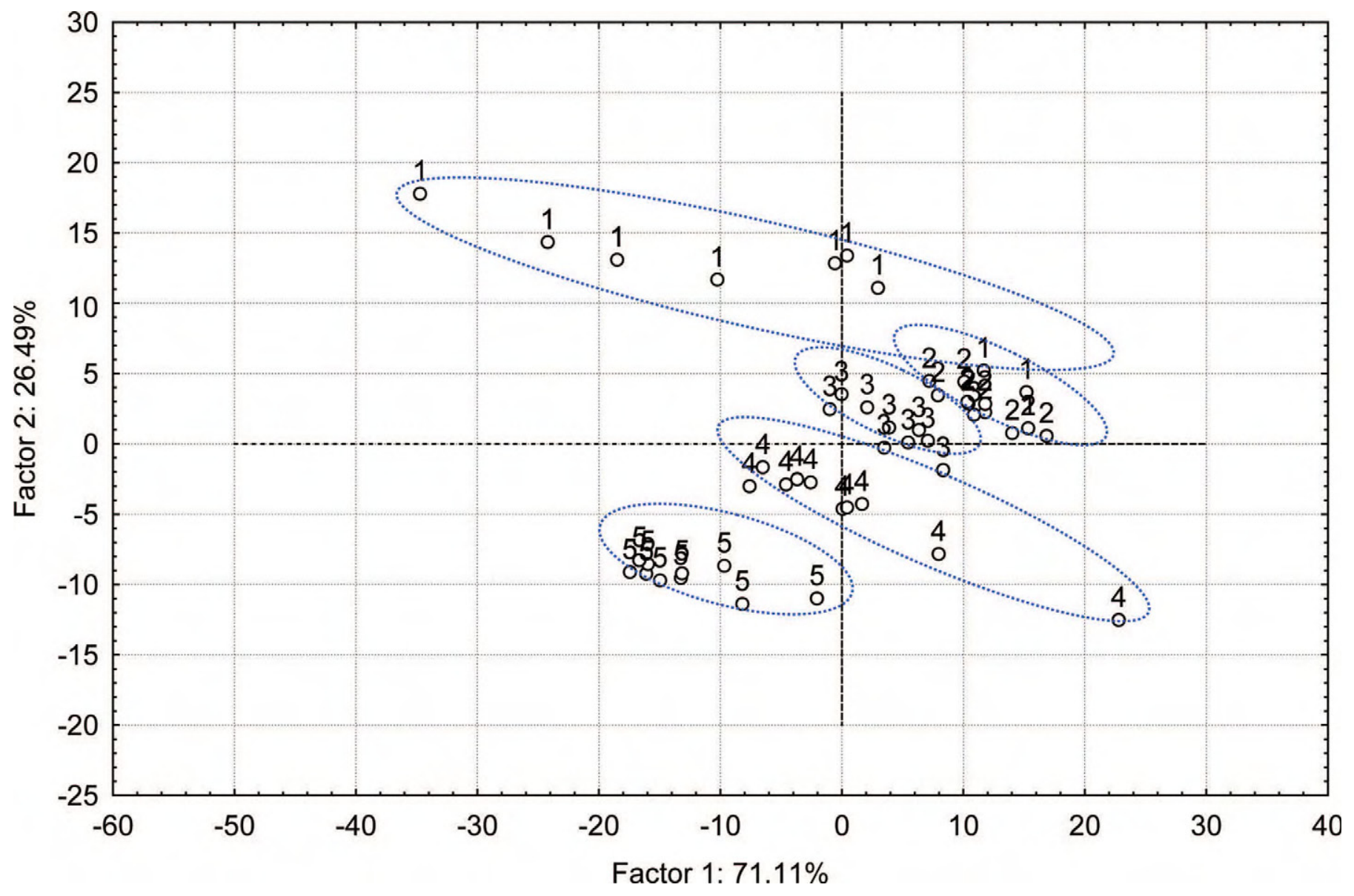

Figure 3. Principal components analysis of Fourier transform infrared attenuated total reflection carbohydrate (CHO) molecular spectrum in the fingerprint region of $\sim 1,539-946 \mathrm{~cm}^{-1}$ obtained from 5 mixtures of a bioethanol processing co-product blend with barley grain (Yu, 2005). $1=$ B100, $100 \%$ barley; $2=$ B75BD25, $75 \%$ barley $+25 \%$ distillers dried grains with solubles (DDGS) blend; $3=$ B50BD50, 50\% barley + $50 \%$ DDGS blend; $4=$ B25BD75, 25\% barley $+75 \%$ DDGS blend; $5=$ BD100, 100\% DDGS blend. Color version available in the online PDF

correlation $(P<0.10)$ between lignin and CA tended to appear. No correlations $(P>0.05)$ were found between lignin and cellulosic spectral feature and energy values. The results indicate an association between spectral features of the chemical functional groups and the chemical and nutrient composition.

Second, no correlation $(P>0.05)$ was found between $\mathrm{STCHO}$ and all the conventional parameters in terms of chemical profiles, $\mathrm{CHO}$ partitions, and truly nutrient digestibility, as well as in situ degradation characteristics. The results indicate that STCHO cannot be used as an indicator to predict nutrient profiles in these feed mixtures.

Third, the spectra of $\mathrm{CHO}$ had a strongly negative correlation $(P<0.01)$ with NDF, ADF, ADL, hemicellulose, cellulose, $\mathrm{CA}, \mathrm{CB}_{2}, \mathrm{CC}$, tdNDF, and the energy value of $\mathrm{NE}_{\mathrm{L} 3 \times}\left(\mathrm{NE}_{\mathrm{L}}\right.$ at 3 times maintenance intake; $P$ $=0.06)$ but had a strong positive correlation $(P<0.01)$ with total $\mathrm{CHO}$, starch, NFC, $\mathrm{CB}_{1}$, tdNFC, TDN $1 \times$, and FOM. No correlation $(P>0.05)$ was found between all spectral intensities of $\mathrm{CHO}$ and energy values. These results indicate that $\mathrm{CHO}$ molecular spectral features in the mixtures were associated with CHO-related chemical and nutrient profiles and could be used as potential predictors.

\section{CONCLUSIONS}

It was concluded that the increasing inclusion of the co-product blend altered the chemical constituents, nutritive characteristics, and spectral features of the intrinsic molecular structure of hull-less barley. Integration with the co-product blend significantly decreased $\mathrm{CHO}$, starch, and NFC, whereas it increased NDF, $\mathrm{ADF}, \mathrm{ADL}$, hemicellulose, and cellulose in the mixture. Subsequently, these changes resulted in a significant decrease in $\mathrm{CB}_{1}$, tdNFC, effective degradable content of DM in the rumen, EDST, and FOM and a significant increase in $\mathrm{CA}, \mathrm{CB}_{2}, \mathrm{CC}$, tdNDF, and bypass DM, 
Table 2. Chemical composition $( \pm \mathrm{SD})$, carbohydrate $(\mathrm{CHO})$ fractions $( \pm \mathrm{SD})$, and TDN $( \pm \mathrm{SD})$ of mixtures ${ }^{1}$ of the co-product blend with barley

\begin{tabular}{|c|c|c|c|c|c|c|c|c|c|c|}
\hline \multirow[b]{2}{*}{ Item $^{2}$} & \multirow[b]{2}{*}{ B100 } & \multirow[b]{2}{*}{ B75BD25 } & \multirow[b]{2}{*}{ B50BD50 } & \multirow[b]{2}{*}{ B25BD75 } & \multirow[b]{2}{*}{ BD100 } & \multirow[b]{2}{*}{$\begin{array}{l}\text { Mean } \pm \text { SD } \\
\quad(\mathrm{n}=5)\end{array}$} & \multirow[b]{2}{*}{$\begin{array}{l}\text { Range from } \\
\text { all data }\end{array}$} & \multicolumn{3}{|c|}{$P$-value } \\
\hline & & & & & & & & Linear & Quadratic & Cubic \\
\hline \multicolumn{11}{|c|}{ Basic chemical composition ( $\mathrm{g} / \mathrm{kg}$ of $\mathrm{DM})$} \\
\hline $\mathrm{DM}(\mathrm{g} / \mathrm{kg})$ & $937 \pm 0.8$ & $932 \pm 0.2$ & $929 \pm 0.3$ & $927 \pm 0.5$ & $923 \pm 0.4$ & $930 \pm 5.3$ & 14 & 0.015 & 0.185 & 0.119 \\
\hline Ash & $17 \pm 0.6$ & $23 \pm 0.1$ & $28 \pm 0.3$ & $35 \pm 0.5$ & $42 \pm 0.1$ & $29 \pm 9.8$ & 25 & 0.019 & 0.325 & 0.690 \\
\hline Ether extract & $20 \pm 0.1$ & $30 \pm 0.1$ & $41 \pm 0.2$ & $49 \pm 0.4$ & $61 \pm 2.1$ & $40 \pm 16.0$ & 41 & 0.026 & 0.872 & 0.602 \\
\hline \multicolumn{11}{|c|}{ Structural and nonstructural CHO profiles (g/kg of DM) } \\
\hline $\mathrm{CHO}$ & $816 \pm 0.6$ & $741 \pm 1.3$ & $672 \pm 5.6$ & $603 \pm 1.9$ & $524 \pm 2.4$ & $671 \pm 114.2$ & 292 & 0.001 & 0.140 & 0.060 \\
\hline Starch & $613 \pm 10.3$ & $514 \pm 7.7$ & $353 \pm 3.4$ & $216 \pm 7.8$ & $58 \pm 0.1$ & $351 \pm 223.2$ & 555 & 0.022 & 0.355 & 0.560 \\
\hline NDF & $100 \pm 2.1$ & $179 \pm 3.1$ & $259 \pm 0.9$ & $341 \pm 0.7$ & $454 \pm 0.8$ & $267 \pm 138.0$ & 354 & 0.008 & 0.113 & 0.216 \\
\hline $\mathrm{ADF}$ & $14 \pm 0.4$ & $33 \pm 1.6$ & $50 \pm 4.4$ & $66 \pm 3.4$ & $93 \pm 2.1$ & $51 \pm 30.3$ & 79 & 0.014 & 0.202 & 0.197 \\
\hline $\mathrm{ADL}$ & $3 \pm 0.1$ & $6.6 \pm 0.7$ & $10 \pm 0.7$ & $15 \pm 0.0$ & $20 \pm 0.3$ & $11 \pm 6.7$ & 17 & 0.019 & 0.212 & 0.902 \\
\hline $\mathrm{NFC}$ & $730 \pm 2.4$ & $612 \pm 5.1$ & $498 \pm 7.9$ & $383 \pm 2.2$ & $233 \pm 4.6$ & $491 \pm 193.7$ & 497 & 0.006 & 0.125 & 0.174 \\
\hline Hemicellulose & $87 \pm 1.7$ & $146 \pm 1.4$ & $208 \pm 3.5$ & $275 \pm 2.8$ & $362 \pm 1.3$ & $216 \pm 107.7$ & 275 & 0.005 & 0.061 & 0.179 \\
\hline Cellulose & $11 \pm 0.3$ & $26 \pm 1.0$ & $40 \pm 3.7$ & $51 \pm 3.4$ & $73 \pm 1.8$ & $40 \pm 23.8$ & 62 & 0.026 & 0.367 & 0.297 \\
\hline \multicolumn{11}{|c|}{ Fractions of carbohydrates (CNCPS, $\mathrm{g} / \mathrm{kg}$ of $\mathrm{CHO}$ ) } \\
\hline $\mathrm{CA}$ & $282 \pm 12.5$ & $312 \pm 16.0$ & $387 \pm 2.2$ & $418 \pm 9.5$ & $386 \pm 6.6$ & $357 \pm 57.3$ & 104 & 0.054 & 0.117 & 0.153 \\
\hline $\mathrm{CB}_{1}$ & $613 \pm 10.3$ & $514 \pm 7.7$ & $353 \pm 3.4$ & $216 \pm 7.8$ & $58 \pm 0.1$ & $351 \pm 223.2$ & 555 & 0.022 & 0.355 & 0.560 \\
\hline $\mathrm{CB}_{2}$ & $96 \pm 2.0$ & $153 \pm 6.2$ & $223 \pm 2.8$ & $307 \pm 1.6$ & $466 \pm 5.0$ & $249 \pm 144.7$ & 370 & 0.016 & 0.078 & 0.223 \\
\hline $\mathrm{CC}^{2}$ & $9 \pm 0.3$ & $21 \pm 2.1$ & $36 \pm 2.8$ & $59 \pm 0.1$ & $90 \pm 1.7$ & $43 \pm 2.2$ & 81 & 0.006 & 0.031 & 0.230 \\
\hline \multicolumn{11}{|c|}{ Truly digestible nutrients and TDN (g/kg of DM) } \\
\hline tdNFC & $715 \pm 0.2$ & $600 \pm 0.5$ & $488 \pm 0.8$ & $375 \pm 0.2$ & $228 \pm 0.5$ & $481 \pm 189.9$ & 487 & 0.006 & 0.125 & 0.183 \\
\hline tdNDF & $55 \pm 0.1$ & $79 \pm 0.3$ & $105 \pm 0.0$ & $129 \pm 0.0$ & $170 \pm 0.1$ & $108 \pm 44.6$ & 115 & 0.020 & 0.198 & 0.334 \\
\hline $\mathrm{TDN}_{1 \times}$ & $870 \pm 1.6$ & $857 \pm 3.4$ & $844 \pm 1.1$ & $823 \pm 0.5$ & $800 \pm 2.2$ & $839 \pm 27.8$ & 70 & 0.019 & 0.140 & 0.770 \\
\hline \multicolumn{11}{|c|}{ Predicted energy values ${ }^{3}$ (Mcal/kg of DM) } \\
\hline $\mathrm{DE}_{1 \times}-$ Dairy & $3.85 \pm 0.007$ & $3.88 \pm 0.017$ & $3.89 \pm 0.005$ & $3.87 \pm 0.001$ & $3.85 \pm 0.011$ & $3.87 \pm 0.018$ & 0.04 & 0.628 & 0.087 & 0.412 \\
\hline $\mathrm{ME}_{\mathrm{P} 3 \times}-$ Dairy & $2.72 \pm 0.003$ & $2.76 \pm 0.008$ & $2.80 \pm 0.006$ & $2.82 \pm 0.002$ & $2.86 \pm 0.006$ & $2.79 \pm 0.054$ & 0.14 & 0.042 & 0.592 & 0.540 \\
\hline $\mathrm{NE}_{\mathrm{L} 3 x}-$ Dairy & $1.72 \pm 0.002$ & $1.75 \pm 0.006$ & $1.78 \pm 0.004$ & $1.80 \pm 0.001$ & $1.83 \pm 0.005$ & $1.78 \pm 0.043$ & 0.11 & 0.027 & 0.592 & 0.540 \\
\hline $\mathrm{NE}_{\mathrm{M}}-$ Beef & $2.39 \pm 0.006$ & $2.41 \pm 0.013$ & $2.42 \pm 0.004$ & $2.41 \pm 0.001$ & $2.40 \pm 0.009$ & $2.41 \pm 0.011$ & 0.03 & 0.328 & 0.106 & 0.540 \\
\hline $\mathrm{NE}_{\mathrm{G}}-$ Beef & $1.67 \pm 0.005$ & $1.69 \pm 0.011$ & $1.70 \pm 0.003$ & $1.69 \pm 0.001$ & $1.68 \pm 0.008$ & $1.69 \pm 0.011$ & 0.03 & 0.328 & 0.106 & 0.540 \\
\hline
\end{tabular}

${ }^{1}$ B100 $=100 \%$ barley; B75BD25 = 75\% barley $+25 \%$ blend distillers dried grains with solubles (DDGS); B50BD $50=50 \%$ barley $+50 \%$ DDGS blend; B25BD75 $=25 \%$ barley + $75 \%$ DDGS blend; BD100 $=100 \%$ DDGS blend

${ }^{2} \mathrm{CNCPS}=$ Cornell Net Carbohydrate and Protein System; CA = fraction composed of sugars and organic acids, which had a rapid degradation rate of $300 \% / \mathrm{h}$ (calculated as CA $\left.=\mathrm{NFC}-\mathrm{CB}_{1}\right) ; \mathrm{CB}_{1}=$ fraction including starch and pectin, which had an intermediate degradation rate of 20 to $50 \% / \mathrm{h}\left(\mathrm{CB}_{1}=\right.$ starch + pectin $) ; \mathrm{CB}_{2}=$ digestible cell wall fraction, which had a slow degradation rate of 2 to $10 \% / \mathrm{h}$ and equaled $\mathrm{NDF}_{\mathrm{n} \text {-free }}$ minus $\mathrm{CC}\left[\mathrm{CB}_{2}=(\mathrm{NDF}-\mathrm{NDICP})-\mathrm{CC}\right]$, where NDICP is neutral detergent-insoluble $\mathrm{CP}$; CC $=$ unavailable cell wall fraction, which were unavailable $\mathrm{CHO}$ in the rumen and were calculated by lignin $[\mathrm{CC}=($ lignin $\times 2.4) / 100] ;$ tdNFC $=$ truly digestible $\mathrm{NFC}$; tdNDF $=$ truly digestible $\mathrm{NDF} ; \mathrm{TDN}_{1 \times}=$ total digestible nutrients at a maintenance level (TDN data were reported in Zhang and Yu, 2012); DE $1 \times=$ digestible energy at maintenance level (NRC, 2001-Dairy); $\mathrm{ME}_{\mathrm{P} 3 \times}=\mathrm{ME}$ at production level at $3 \times$ maintenance intake (NRC, 2001-Dairy); $\mathrm{NE}_{\mathrm{L} 3 \times}=\mathrm{NE}_{\mathrm{L}}$ at 3 times maintenance intake $(\mathrm{NRC}, 2001-\mathrm{Dairy}) ; \mathrm{NE}_{\mathrm{M}}=\mathrm{NE}_{\mathrm{M}}$ in the growing animal (NRC, 1996-Beef); $\mathrm{NE}_{\mathrm{G}}=\mathrm{NE}_{\mathrm{G}}$ or net energy for retention (NRC, 1996-Beef)

${ }^{3}$ NRC (2001)-Dairy and NRC (1996)-Beef. 
Table 3. Characteristics of in situ starch rumen degradability of the mixtures ${ }^{1}$ of co-product blend with barley

\begin{tabular}{|c|c|c|c|c|c|c|c|c|c|}
\hline $\begin{array}{l}\text { Characteristics of in } \\
\text { situ starch rumen } \\
\text { degradation }\end{array}$ & B100 & B75BD25 & B50BD50 & B25BD75 & BD100 & SEM & \multicolumn{3}{|c|}{$P$-value } \\
\hline $\mathrm{K}_{\mathrm{d}}(\% / \mathrm{h})$ & 17.43 & 18.50 & 16.55 & 15.52 & 14.49 & 2.084 & 0.214 & 0.669 & 0.643 \\
\hline D (\% of starch) & 70.8 & 63.4 & 85.1 & 71.0 & 78.2 & 8.99 & 0.408 & 0.832 & 0.766 \\
\hline$\%$ BST & 21.3 & 19.3 & 24.1 & 22.7 & 26.1 & 2.89 & 0.214 & 0.694 & 0.832 \\
\hline BST $(\mathrm{g} / \mathrm{kg}$ of $\mathrm{DM})$ & $130^{\mathrm{a}}$ & $99^{\mathrm{a}}$ & $85^{\mathrm{ab}}$ & $49^{\mathrm{bc}}$ & $15^{\mathrm{c}}$ & 8.1 & $<0.001$ & 0.406 & 0.572 \\
\hline
\end{tabular}

${ }^{\mathrm{a} e}$ Means with superscript letters in the same row are significantly different $(P<0.05)$.

${ }^{1} \mathrm{~B} 100=100 \%$ barley; B75BD25 $=75 \%$ barley $+25 \%$ distillers dried grains with solubles (DDGS) blend; B50BD50 = 50\% barley $+50 \%$ DDGS blend; B25BD75 $=25 \%$ barley $+75 \%$ DDGS blend; BD100 $=100 \%$ DDGS blend.

${ }^{2} K_{d}=$ the rate of degradation of the $\mathrm{d}$ fraction; $\mathrm{S}=$ soluble fraction in the in situ incubation; $\mathrm{D}=$ insoluble but potentially degradable fraction in the in situ incubation; \%BST = starch fraction of the bypass rumen; BST = starch of the bypass rumen; \%EDST = effectively degradable fraction of starch in the rumen; EDST = effectively degradable starch in the rumen; FOM = fermentable OM (FOM data were reported in Zhang and $\mathrm{Yu}, 2012$ ).

which could improve the feed quality of both the coproduct blend and the hull-less barley in dairy cattle.

\section{ACKNOWLEDGMENTS}

We are grateful to the Agriculture Development Fund (SK, Canada), Beef Cattle Research Council (BCRC)- science (Calgary, AB, Canada), Natural Sciences and Engineering Research Council of Canada (NSERC, Ottawa, ON, Canada), and Ministry Agriculture Strategic Research Chair Program (SK, Canada) for financial support of the feed research program and postdoctoral fellowship fellowship to Xuewei Zhang. The author especially thanks the researcher Z. Niu and graduate

Table 4. Correlation between carbohydrate $(\mathrm{CHO})$ molecular structural spectral profiles vs. CHO nutrient profiles of the mixtures of co-product blend with barley

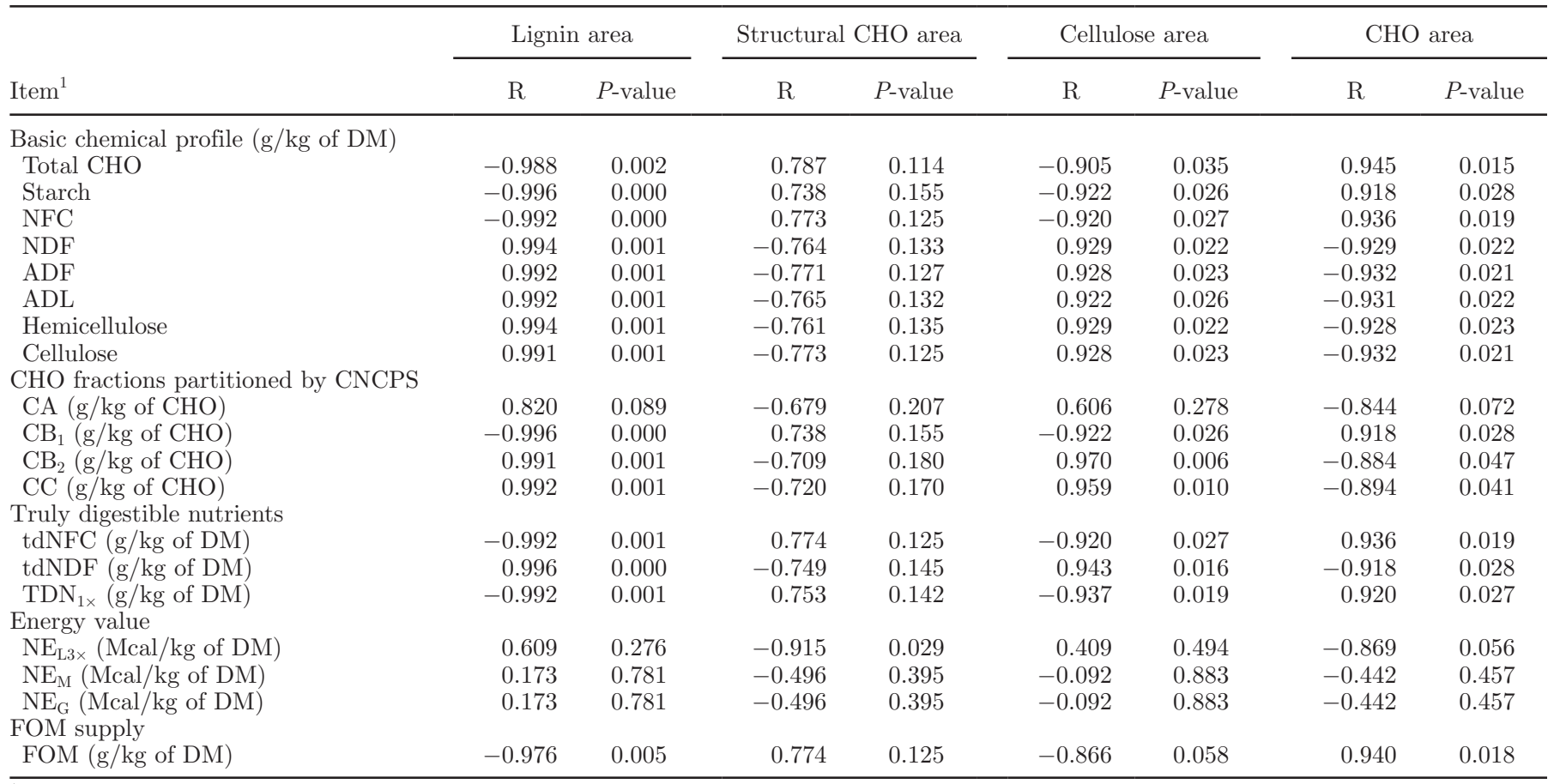

${ }^{1}$ CNCPS $=$ Cornell Net Carbohydrate and Protein System; CA = fraction composed of sugars and organic acids, which had a rapid degradation rate of $300 \% / \mathrm{h}$ (calculated as $\mathrm{CA}=\mathrm{NFC}-\mathrm{CB}_{1}$ ) $\mathrm{CB}_{1}=$ fraction including starch and pectin, which had an intermediate degradation rate of 20 to $50 \% / \mathrm{h}\left(\mathrm{CB}_{1}=\right.$ starch + pectin $) ; \mathrm{CB}_{2}=$ digestible cell wall fraction, which had a slow degradation rate of 2 to $10 \% / \mathrm{h}$ and equaled $\mathrm{NDF}_{\mathrm{n}}$ free minus $\mathrm{CC}\left[\mathrm{CB}_{2}=(\mathrm{NDF}-\mathrm{NDICP})-\mathrm{CC}\right]$, where NDICP is neutral detergent insoluble $\mathrm{CP}$; $\mathrm{CC}=$ unavailable cell wall fraction, which were unavailable $\mathrm{CHO}$ in the rumen and were calculated by lignin $[\mathrm{CC}=($ lignin $\times 2.4) / 100]$; tdNFC $=$ total truly digestible NFC; tdNDF $=$ total truly digestible $\mathrm{NDF} ; \mathrm{TDN}_{1 \times}=$ total digestible nutrients at a maintenance level; $\mathrm{NE}_{\mathrm{L} 3 \times}=\mathrm{NE}_{\mathrm{L}}$ at 3 times maintenance intake; FOM $=$ fermentable OM. 
student Liu Bo for providing laboratory assistance and assistance with data analysis.

\section{REFERENCES}

Abeysekara, S., D. Damiran, and P. Yu. 2011. Spectroscopic impact on protein and carbohydrate inherent molecular structures of barley, oat and corn combined with wheat DDGS. Spectroscopy 26:4-5.

AOAC. 1990. Official Methods of Analysis. Assoc. Off. Anal. Chem., Washington, DC.

Bhatty, R. S. 1986. The potential of hull-less barley-A review. Cereal Chem. 63:97-103.

Bhatty, R. S. 1999. Review: The potential of hull-less barley. Cereal Chem. 76:589-599.

CCAC (Canadian Council on Animal Care). 1993. Guide to the Care and Use of Experimental Animals. 2nd ed. Can. Counc. Anim. Care, Ottawa, ON, Canada.

Damiran, D., A. Jonker, M. Yari, J. J. McKinnon, T. McAllister, and P. Yu. 2012. Effect of wheat-based dried distillers' grains with solubles inclusion on barley-based feed chemical profile, energy values, rumen degradation kinetics, and protein supply. J. Agric. Food Chem. 60:4986-4993.

Damiran, D., and P. Yu. 2010. Chemical profile, rumen degradation kinetics and energy value of four hull-less barley cultivars: Comparison of the zero-amylose waxy, waxy, and high-amylose and normal starch cultivars. J. Agric. Food Chem. 58:10553-10559.

Damiran, D., and P. Yu. 2012. Metabolic characteristics of the proteins of newly developed hulless barley varieties with altered starch traits in Ruminants. J. Cereal Sci. (UK) 60:4986-4993.

Doiron, K. J., P. Yu, C. R. Christensen, D. A. Christensen, and J. J. Mckinnon. 2009. Detecting molecular changes in Vimy flaxseed protein structure using synchrotron FTIRM and DFTIR spectroscopic techniques: Structural and biochemical characterization. Spectroscopy 23:307-322.

Fox, D. G., L. O. Tedeschi, T. P. Tylutky, J. B. Russell, M. E. Van Amburgh, L. E. Chase, C. Lanzas, C. J. Sniffen, S. Seo, L. O. Tedeschi, and D. G. Fox. 2007. A revised CNCPS feed carbohydrate fraction scheme for formulating rations for ruminants. Anim. Feed Sci. Technol. 136:167-190.

Himmelsbach, D. S., S. Khalili, and D. E. Akin. 1998. FT-IR microspectroscopic imaging of flax (Linum usitatissimum L.) stems. Cell. Mol. Biol. (Noisy-Le-Grand) 44:99-108.

Jonker, A., M. Y. Gruber, Y. Wang, B. Coulman, J. J. McKinnon, D. A. Christensen, and P. Yu. 2012. Foam stability of leaves from anthocyanidin-accumulating Lc-alfalfa and relation to molecular structures detected by FTIR vibration spectroscopy. Grass Forage Sci. (UK). http://dx.doi.org/10.1111/j.1365-2494.2012.00853.x.

Liu, N., and P. Yu. 2010. Characterization of the microchemical structure of seed endosperm within a cellular dimension among six barley varieties with distinct degradation kinetics, using ultraspatially resolved synchrotron-based infrared microspectroscopy. J. Agric. Food Chem. 58:7801-7810.

Marinkovic, N. S., and M. R. Chance. 2006. Synchrotron infrared microspectroscopy. Pages 671-708 in Encyclopedia of Molecular Cell Biology and Molecular Medicine. 2nd ed. R. Meyers, ed. Wiley Inc., New York, NY.

McCleary, B. V., C. C. Gibson, and C. C. Mugford. 1997. Measurements of total starch in cereal products by amyloglucosidase alphaamylase method: Collaborative study. J. AOAC Int. 80:571-579.

NRC. 1996. Nutrient Requirement of Beef Cattle. 7th ed. Natl. Acad. Press, Washington, DC.

NRC. 2001. Nutrient Requirements of Dairy Cattle. 7th ed. Natl Acad. Press, Washington, DC.

Nuez-Ortín, W. G., and P. Yu. 2009. Nutrient variation and availability of wheat DDGS, corn DDGS and blend DDGS from bioethanol plants. J. Sci. Food Agric. 89:1754-1761.

Nuez-Ortín, W. G., and P. Yu. 2010a. Effects of bioethanol plant and co-products type on the metabolic characteristics of the proteins. J. Dairy Sci. 93:3775-3783.
Nuez-Ortín, W. G., and P. Yu. 2010b. Estimation of ruminal and intestinal digestion profiles, hourly degradation ratio and potential $\mathrm{N}$ to energy synchronization of co-products of bioethanol production. J. Sci. Food Agric. 90:2058-2067.

Ørskov, E. R., and I. McDonald. 1979. The estimation of protein degradability in the rumen from incubation measurements weighed according to rate of passage. J. Agric. Sci. (Camb.) 92:499-503.

Ramsey, P. B., G. W. Mathison, and L. A. Goonewardene. 2001. Relationships between ruminal dry matter and starch disappearance and apparent digestibility of barley grain. Anim. Feed Sci. Technol. 94:155-170.

SAS Institute. 2005. User's Guide Statistics. Version 9.2. SAS Inst. Inc., Cary, NC.

Sniffen, C. J., J. D. O'Connor, P. J. Van Soest, D. G. Fox, and J. B. Russell. 1992. A Net Carbohydrate and Protein System for Evaluating Cattle Diets: II. Carbohydrate and Protein Availability. J. Anim. Sci. 70:3562-3577.

Tamminga, S., W. M. Van Straalen, A. P. J. Subnel, R. G. M. Meijer, A. Steg, C. J. Wever, and M. C. Blok. 1994. The Dutch protein evaluation system: The DVE/OEB-system. Livest. Prod. Sci. 40:139-155.

Van Soest, P. J., J. B. Robertson, and B. A. Lewis. 1991. Methods for dietary fiber, neutral detergent fiber, and nonstarch polysaccharides in relation to animal nutrition. J. Dairy Sci. 74:3583-3597.

Wetzel, D. L. 2001. When molecular causes of wheat quality are known, molecular methods will supercede traditional methods. Pages 1-20 in Proc. 2nd Int. Wheat Quality Conf., Manhattan, KS.

Wetzel, D. L., A. J. Eilert, L. N. Pietrzak, S. S. Miller, and J. A Sweat. 1998. Ultraspatially resolved synchrotron infrared microspectroscopy of plant tissue in situ. Cell. Mol. Biol. 44:145-168.

Yang, W. Z., B. A. Beauchemin, B. I. Farr, and L. M. Rode. 1997 Comparison of barley, hull-less barley, and corn in the concentrate of dairy cows. J. Dairy Sci. 80:2885-2895.

Yu, P. 2005. Applications of hierarchical cluster analysis (CLA) and principal component analysis (PCA) in feed structure and feed molecular chemistry research, using synchrotron-based Fourier transform infrared (FTIR) microspectroscopy. J. Agric. Food Chem. 53:7115-7127.

Yu, P. 2010. Plant-based food and feed protein structure changes induced by gene-transformation, heating and bio-ethanol processing: A novel synchrotron-based molecular structure and nutrition research program. Mol. Nutr. Food Res. 54:1535-1545.

Yu, P. 2012. Relationship of carbohydrate molecular spectroscopic features to carbohydrate nutrient profiles in co-products from bioethanol production. J. Dairy Sci. 95:2091-2096.

Yu, P., H. C. Block, and K. Doiron. 2009. Understanding the differences in molecular conformation of carbohydrate and protein in endosperm tissues of grains with different biodegradation kinetics using advanced synchrotron technology. Spectrochim. Acta A Mol. Biomol. Spectrosc. 71:1837-1844.

Yu, P., D. Damiran, A. Azarfar, and Z. Niu. 2011. Detecting molecular features of spectra mainly associated with structural and nonstructural carbohydrates in co-products from bioethanol production using DRIFT with uni- and multi-variate molecular spectral analyses. Int. J. Mol. Sci. 12:1921-1935.

Yu, P., J. A. Meier, D. A. Christensen, B. G. Rossnagel, and J. J. McKinnon. 2003. Using the NRC-2001model and the DVE/OEB system to evaluation nutritive values of Harrington (malting-type) and Valier (feed-type) barley for ruminants. Anim. Feed Sci. Technol. 107:45-60.

Zhang, X., and P. Yu. 2012. Using ATR-FT/IR molecular spectroscopy to detect effects of blend DDGS inclusion level on the molecular structure spectral and metabolic characteristics of the proteins in hulless barley. Spectrochim. Acta A Mol. Biomol. Spectrosc. 95:53-63.

Zinn, R. A., M. Montano, and Y. Shen. 1996. Comparative feeding value of hull-less vs. covered barley for feedlot cattle. J. Anim. Sci. 74:1187-1193. 